\title{
ANALISIS KEGAGALAN PRODUK PRESERED CONCRETE GIRDER I AKIBAT DEFORMASI CETAKAN DENGAN MENGGUNAKAN METODE ELEMEN HINGGA
}

\author{
Eko Teguh Fiji Santoso ${ }^{1}$, Choirul Anwar ${ }^{1}$, Ghani Heryana ${ }^{1}$ \\ ${ }^{1}$ Jurusan Teknik Mesin Sekolah Tinggi Teknologi Wastukancana \\ Eko.teguh.f.s@gmail.com,Choirul@stt-wastukancana.co.id,Tosidagama@gmail.com
}

\begin{abstract}
ABSTRAK
Presered concret I girder merupakan desain bentuk girder yang paling banyak digunakan pada bangunan struktur jembatan dan flyover di Indonesia, Untuk produksi PCI Girder memerlukan cetakan yang cukup kuat untuk menahan tekanan yang terjadi. Namun dalam kondisi aktual cetakan tidak mampu menahan tekanan beton dan getaran vibrator sehingga terjadi deformasi cetakan yang mengakibatkan dimensi produk berubah dari desain awal. Oleh karena itu untuk menganalisis masalah deformasi cetakan perlu dilakukan pengumpulan data aktual kemudian melakukan analisis yang terjadi pada cetakan.
\end{abstract}

Salah satu metode yang dapat dipakai untuk menganalisis pergeseran cetakan yaitu dengan metode elemen hingga. Dari analisis metode elemen hingga yang dilakukan dengan menggunakan Solidworks, dari hasil analisis maka didapatkan tegangan maksimal yang terjadi $477200000 \mathrm{~N} / \mathrm{m}^{2}$ nilai tersebut melebihi yield strength matrial $206807000 \mathrm{~N} / \mathrm{m}^{2}$ sehingga cetakan mengalami lendutan $2,25 \mathrm{~mm}$ serta pengaruh dari getaran vibrator dengan nilai lendutan sebesar 0,074 $\mathrm{mm}$.

Setelah analisis dilakukan maka tindakan rekomendasi dilakukan dengan cara menambah rangka dengan baja jenis UNP atau clamping untuk dudukan bracing dibagian tengah cetakan, kemudian dilakukan analisis statis sehingga nilai von mises dari cetakan berubah menjani nilai maksimal : $329800000 \mathrm{~N} / \mathrm{m}^{\wedge} 2$ dan lendutan berkurang menjadi $0,952 \mathrm{~cm}$.

Kata kunci: PCI Girder, metode elemen hingga, difleksi cetakan

\section{PENDAHULUAN}

\subsection{Latar Belakang}

Hal yang mendasari dari pernelitian ini dikarenakan cacat produksi Presered Concrete I girder yang mengakibatkan dimensi berubah mengakibatkan berat dan volume berubah, sehingga menambah anggaran biaya untuk menambah jumlah material serta dapat mengurangi kapasitas beban maksimum kendaraan dari desain rencana. Untuk mengurangi cacat produksi maka perlu dilakukan analisis kegagalan cetakan Presered Concrete I girder dengan menggunakan metode elemen hingga, sehingga dari analisis tersebut dapat diketahui penyebab kegagalan produksi akibat deformasi cetakan kemudian dapat dilakukan tindakan selanjutnya.

\subsection{Batasan Masalah}

Agar pembahasan dapat terpusat dan terarah sesuai dengan tema metode penelitian ini, maka ditetapkan batasan masalah yaitu:
Penelitian ini hanya menganalisis tekanan yang terjadi pada cetakan dan distribusi getaran vibrator dengan menggunakan metode elemen hingga.

\section{TINJAUAN PUSTAKA}

\subsection{Presered Concrete I Girder}

Presered concrete I girder adalah sebuah balok beton yang terletak diantara dua penyangga dapat berupa pier ataupun abutment pada suatu jembatan atau flyover dengan profil I. Presered concrete I girder merupakan desain bentuk girder yang paling banyak digunakan pada bangunan struktur jembatan dan flyover di Indonesia. Profil PCI girder berbentuk penampang I dimana bagian tengahnya mempunyai dimensi lebih kecil dari bagian sayapnya sehingga berat $P C I$ girder relatif lebih ringan dan dianggap paling ekonomis jika dibandingkan jenis girder lainya, namun untuk memproduksi PCI girder terdapat masalah yang menyebabkan dimensi produk berubah. 


\subsection{Pengertian Metode Elemen Hingga}

Metode Elemen Hingga atau biasanya disebut Finite Element Analysis (FEA) adalah metode numerik yang dipakai untuk menyelsaikan masalah-masalah dalam bidang rekayasa (engineering), seperti analisa tegangan pada struktur, frekuensi pribadi dan mode shape-nya, perpindahaan panas, elektromagnetis, dan aliran fluida.

Metode ini digunakan pada masalahmasalah rekayasa dimana exact solution/analytical solution tidak dapat menyelsaikannya. Inti dari FEA adalah membagi suatu benda yang akan dianalisa, menjadi beberapa bagian dengan jumlah hingga (finite). Bagian-bagian ini disebut elemen yang tiap elemen satu dengan elemen lainnya dihubungkan dengan nodal (node). Kemudian dibangun persamaan metrik matematika yang menjadi reprensentasi benda tersebut. Proses pembagian benda menjadi beberapa bagian disebut meshing.

\subsection{Pengertian Cetakan}

Cetakan adalah sebuah alat yang digunakan pada proses produksi dengan cara membentuk bahan mentah (material cair) sesuai dimensi kemudian mengeras material cair tersebut di dalam sehingga terbentuk produk yang sesuai geometri yang akan dibuat. Cetakan presered concrete I girder dibuat dengan menggunakan pelat baja mild steel jenis baja A36 yang berbentuk dinding dan terdapat frame pada bagian luarnya.

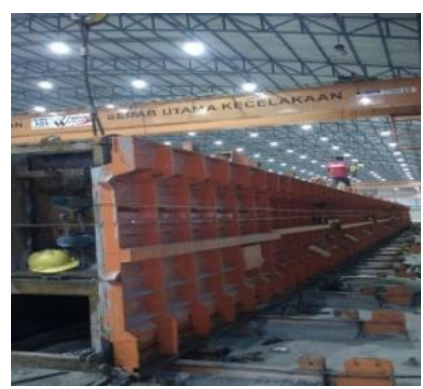

Gambar 1. Cetakan girder PT. XYZ

Tabel 1. Mekanikal Properti ASTMA36

\begin{tabular}{|l|l|l|}
\hline Property & Value & Units \\
\hline Elastic Modulus & $2 \mathrm{e}+011$ & $\mathrm{~N} / \mathrm{m}^{\wedge} 2$ \\
\hline Poisson's Ratio & 0.26 & $\mathrm{~N} / \mathrm{A}$ \\
\hline Shear Modulus & $7.9 \mathrm{e}+010$ & $\mathrm{~N} / \mathrm{m}^{\wedge} 2$ \\
\hline Mass Density & 8000 & $\mathrm{~kg} / \mathrm{m}^{\wedge} 3$ \\
\hline Tensile Strength & 517017000 & $\mathrm{~N} / \mathrm{m}^{\wedge} 2$ \\
\hline Compressive Strength & & $\mathrm{N} / \mathrm{m}^{\wedge} 2$ \\
\hline Yield Strength & 206807000 & $\mathrm{~N} / \mathrm{m}^{\wedge} 2$ \\
\hline Thermal Expansion Coefficient & $1.1 \mathrm{e}-005$ & $/ \mathrm{K}$ \\
\hline
\end{tabular}

Sumber : Solidwork 2016
Terdapat beberapa komponen yang ada pada cetakan antara lain:

1. Baut adalah komponen permesinan yang terbuat dari baja, berbentuk tabung dengan ulir di bagian luar dan mur merupakan fasteners dengan aplikasi pemakaian sebagai pasangan dari bolt. Baut disini yang dipakai untuk menyambung cetakan menggunakan baut dengan kelas 8.8 dengan tegangan leleh (fy) $640 \mathrm{Mpa}$ dan tegangan putus (fu) yaitu $800 \mathrm{Mpa}$.

2. Bracing adalah komponen cetakan yang berfungsi sebagai penopang cetakan pada berbagai arah untuk menghindari terjadinya perubahan posisi terutama pada saat pengecoran. Material yang digunakan adalah pipa baja dengan kedua ujung terpasang baja dengan bentuk silinder pejal dan terdapat ulir segi empat.

3. Vibrator adalah salah satu alat yang digunakan saat pengecoran dimana alat ini berfungsi untuk memadatan beton yang dituangkan dalam cetakan untuk mengeluarkan udara yang terjebak dalam campuran beton sehingga produk yang dihasilkan mendapatkan kekuatan yang merata dan juga untuk menghindari adanya keropos. Terdapat 2 jenis vibrator yaitu : vibrator external dan vibrator internal.

4. Tierod adalah alat bantu berbentuk baja silinder berongga dengan sambungan ulir di kedua sisi yang berfungsi untuk mengunci cetakan bagian atas sehingga pada saat proses pengecoran dilakukan, cetakan tidak mengalami pergeseran. Tierod ini biasanya menggunakan pipa baja berdiammeter $10 \mathrm{~mm}$ dan panjang tergantung dimensi cetakan

\subsection{Tekanan Hidrostatik}

Tekanan Hidrostatik adalah tekanan pada zat cair yang diam sesuai dengan namanya (hidro : air dan static : diam). Atau lebih lengkapnya tekanan hidrostatik didefinisikan sebagai tekanan yang diberikan oleh cairan pada kesetimbangan karena pengaruh gaya gravitasi bumi. [9]

Hal ini berarti setiap benda yang berada di suatu wadah pada zat cair yang diam, tekanannya tergantung dari besarnya gravitasi, kedalaman/ketinggian benda terhadap permukaan zat cair dan massa jenis zat cair. [9] 


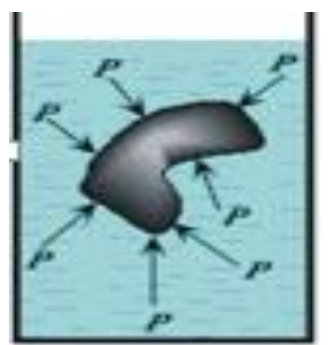

Gambar 2. Tekanan Pada Benda

http://phisiceducation09.blogspot.com diakses 17.36 Juli 2019

Dari gambar di atas maka di dapatkan persamaan untuk menghitung tekanan hidrostatis dengan menggunakan rumus :

$$
\begin{aligned}
& P=\frac{F}{A}=\frac{m \cdot g}{A} \\
& m=p \cdot V \\
& P=\frac{p \cdot V \cdot g}{A}
\end{aligned}
$$

\subsection{Konsep Tumpuan Sendi}

Balok adalah elemen struktur yang dominan memikul gaya dalam berupa momen lentur dan juga geser.

1. Balok sederhana atau bertumpuan sederhana yaitu sebuah balok dengan dua tumpuan dikedua ujungnya.

2. Balok kantilever yaitu balok dengan tumpuan jepit diujung satunya dan bebas diujung lainnya.

3. Balok overhang (bagian overstek) yaitu balok dengan tumpuan diujung balok dan tumpuan.

\subsection{Jenis Beban}

Beban adalah suatu benda mati maupun hidup yang mempunyai massa

dan berada diatas suatu struktur baik balok, kolom maupun pelat dengan beban terpusat/ titik.

Contoh: manusia, tiang lampu dll.

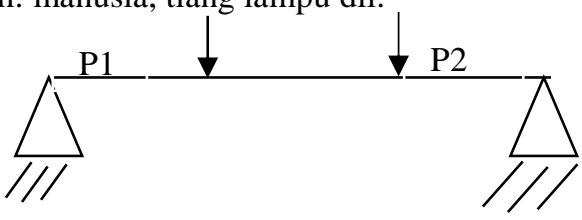

Gambar 3. Beban Terpusat
Beban terdistribusi, terbagi dua yaitu terdistribusi merata dan terdistribusi variasi. Beban ada jika suatu beban memiliki luasan bidang beban dalam menumpu struktur. Contoh: keramik, tempat tidur dll.
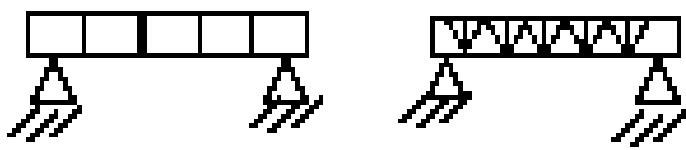

Gambar 4. Distribusi Merata

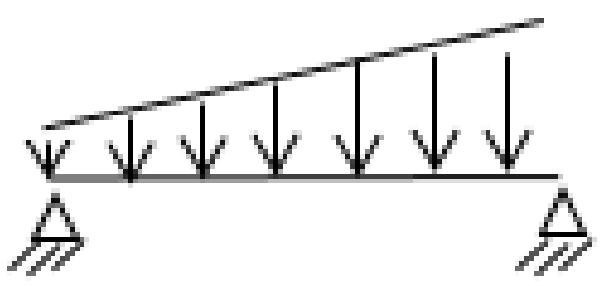

Gambar 5. Distribusi Variasi

Sumber : Ferdinand L Singer, Andrew Pytel Ilmu Kekuatan Bahan Erlangga 1995

\subsubsection{Jenis- jenis Reaksi Gaya:}

Semua yang berkaitan dengan balok akan penentuan gaya reaksi yang bekerja pada balok itu sendiri. Bila terdapat beberapa gaya bekerja dalam satu bidang, maka tiga persamaan keseimbangan statika harus tersedia. Untuk balok pada umumnya yang berbentuk lurus dalam kedudukan yang horizontal, maka sumbu $\mathrm{x}$ akan diambil sebagai arah yang horizontal, sumbu y untuk arah yang vertikal dan sumbu $\mathrm{Z}$ yang arah gayanya tegak lurus terhadap bidang.benda. Penggunaan ketiga persamaan pada beberapa persoalan balok bertujuan untuk melakukan peninjauan lebih mendalam tentang reaksi di setiap tumpuan dan defleksi pada bagian di sepanjang balok. Untuk balok-balok yang stabil dalam jumlah gaya yang kecil, deformasi tidak begitu terlihat besar lendutanya. [6]

1. Gaya horizontal $(\mathrm{H})$ adalah gaya yang bekerja searah atau mendatar pada bidang struktur.

2. Gaya vertikal / Gaya geser (V / R) adalah gaya yang bekerja tegak lurus pada bidang struktur.

3. Gaya Putar/ Momen (M) adalah gaya yang dapat memutar suatu struktur, dapat berada dimana saja dan untuk mengetahui besarnya dengan mengali jarak dan gaya vertical yang ada. 


$$
\begin{aligned}
& \Sigma \mathrm{Fx}=0 \mathrm{RHA}=0 \\
& \Sigma \mathrm{Fy}=0 \mathrm{RVA}+\mathrm{RVB}-\mathrm{F} 1=0 . \ldots \ldots \ldots \ldots \\
& M A=0 F . A-R V B . L \\
& M B=0 F . B-\text { RVA. } L
\end{aligned}
$$

Sedangkan untuk mencari momen maksimum dan lendutan dapat menggunakan persamaan berikut:

$$
\begin{aligned}
& \operatorname{Mmax} \frac{\mathrm{WL}}{8} \\
& \sigma=\frac{\mathrm{M}}{\mathrm{S}}=\frac{\mathrm{My}}{\mathrm{I}} \\
& \delta \frac{5 \mathrm{ML}}{384 \mathrm{EI}} \\
& E I y \frac{W I^{3}}{384}
\end{aligned}
$$

\subsection{Konsep Tegangan -Regangan}

Pada dasarnya tegangan dapat didefinisikan sebagai besaran gaya yang bekerja pada suatu satuan luas. Dirumuskan sebagai berikut :

Tegangan $\sigma=\frac{\mathrm{F}}{\mathrm{A}}$

Dimana :

$[F] \quad$ : Gaya yang bekerja $(\mathrm{N})$

[A] : Luas bidang $\left(\mathrm{mm}^{2}\right)$

Pada suatu bidang yang dikenai suatu gaya akan terdapat dua jenis tegangan yang mempengaruhi bidang tersebut, yaitu tegangan normal dan tegangan geser. Tegangan normal adalah tegangan yang tegak lurus terhadap permukaan benda dari gaya aksial dan momen lentur.

\subsection{Inersia Bidang}

Untuk menggunakan rumus lenturan, maka momen inersia penampang dapat ditentukan dengan integrasi $y^{2} d A$. Untuk mendapatkan momen inersia suatu luas yang terdiri dari bentuk sederhana, maka diperlukan teorema sumbu sejajar. [5]

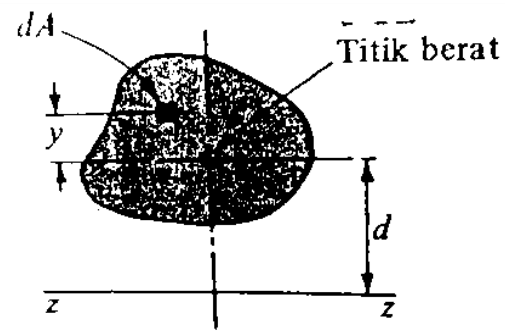

Gambar 6. Inersia Bidang (i) momen inersia terhadap sumbu $I_{z z}$ : $\int(d+y)^{2} d A$

Dimana sebelumnya y diukur dari sumbu yang melalui titik berat dengan mengkuadratkan konstanta keluar tanda integral.

$I_{z z}=d^{2 \int A} d A+2 d \int A y d A+\int A y^{2} d A=$ $A d^{2}+2 d \int A y d A+I_{0}$

Akan tetapi, karena sumbu y di ukur dari titik berat dari daerah luas, maka : $\int y d A$ adalah nol.

$$
\begin{aligned}
& I_{z z} I_{0}+A d^{2} \\
& I a x=\frac{1}{12} b h^{3} . \\
& I a y=\frac{1}{12} b^{3} \mathrm{~h} . \\
& I b x=\frac{1}{12} b h^{3} . \\
& I b y=\frac{1}{12} b^{3} \mathrm{~h} .
\end{aligned}
$$

Satuan momen inersia adalah : I : (mm4) / cm4 atau $\mathrm{m} 4$, tergantung satuan dasar yang digunakan.

\subsection{Konsep Getaran Mekanis}

Getaran adalah suatu gerak bolak balik di sekitar pusat kesetimbangan. Kesetimbangan disini yang di maksud adalah keadaan suatu benda berada pada posisi diam bila tidak terjadi gaya yang bekerja pada benda tersebut. Getaran mempunyai amplitudo (Jarak simpangan terjauh dari titik tengah) yang sama. [1]

Gambar 7. Gelombang Tranversal

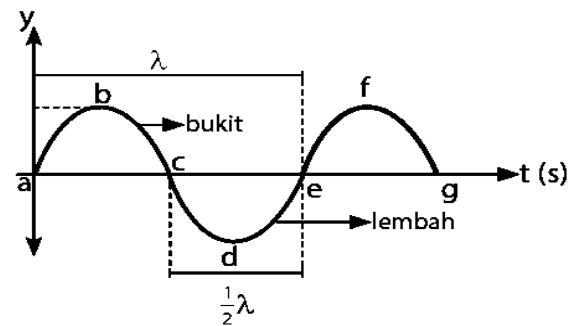

Sumber : Jurnal analisis karakteristik getaran

Dasar analisis getaran dapat dipelajari dengan menghitung rumus cepat rambat gelombang dinyatakan sebagai berikut.

$$
\begin{aligned}
\lambda & =\mathrm{VxTV} / \mathrm{f}^{3} \\
F & =\frac{n}{t} \quad \ldots \ldots . . . \\
T & =\frac{t}{n} \quad \ldots \ldots . . . \\
T & =\frac{1}{f} \quad \ldots \ldots \ldots
\end{aligned}
$$


Maka: $V=\frac{\lambda}{T}$ atau $V=\frac{\lambda}{f}$

Dimana :

$\lambda=$ Panjang gelombang (meter)

$\mathrm{v}=$ Cepat rambat gelombang $(\mathrm{m} / \mathrm{s})$

$\mathrm{f}=$ frekuensi gelombang (detik)

$\mathrm{n}=$ Jumlah gelombang

$\mathrm{T}=$ Periode $($ detik $)$

$\mathrm{t}=\mathrm{Waktu}($ detik $)$

\section{METODOLOGI}

\subsection{Diagram alir perancangan}

Garis besar langkah kerja penelitian dapat dibuat program flow chart seperti di bawah ini :

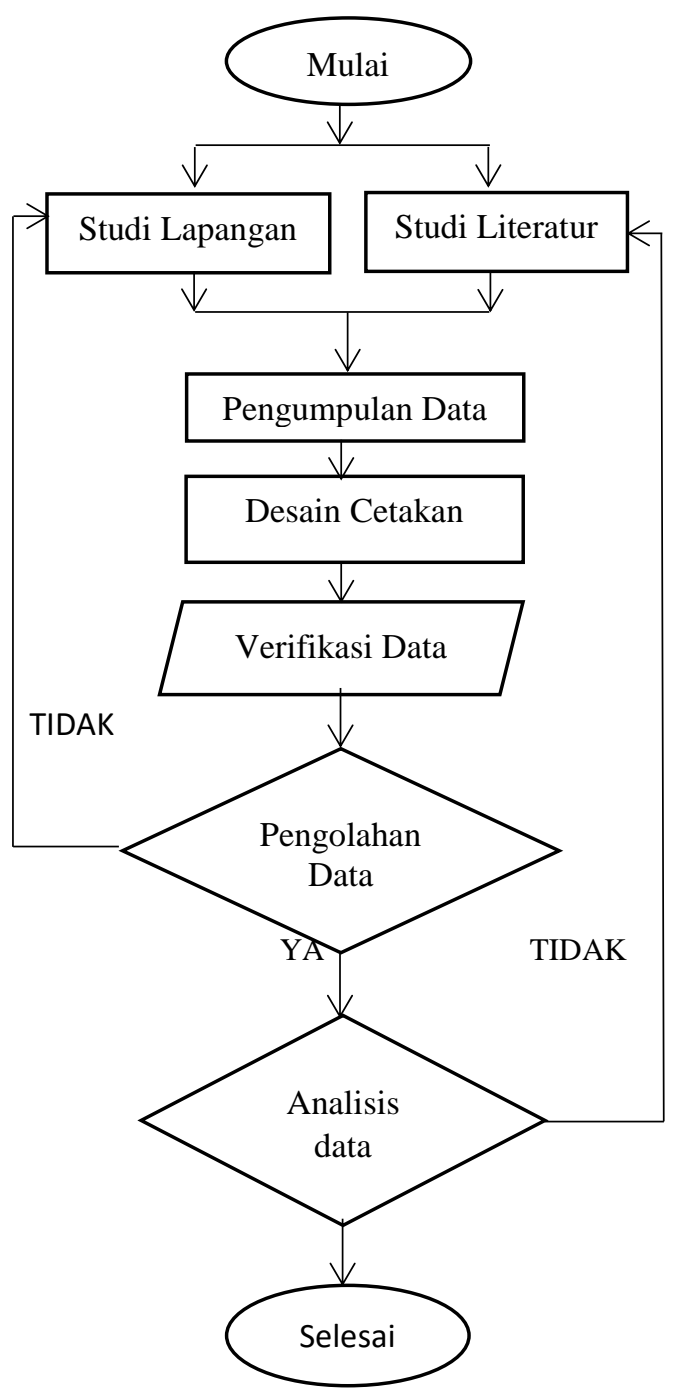

Gambar 8. Langkah kerja

\section{PEMBAHASAN}

\subsection{Volume Cetakan}

Untuk menghitung dan menganalisa tekanan yang terjadi pada cetakan khususnya di segmen 3, maka perlu dilakukan perhitungan volume beton yang berada pada cetakan mulai dari segmen 1-5.
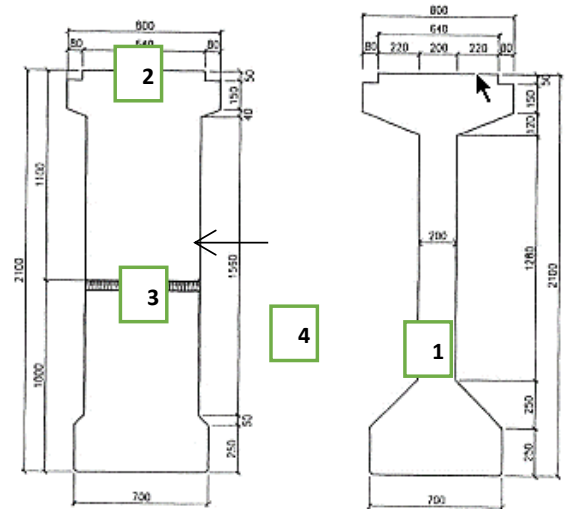

Gambar 9. Girder Tampak Depan

Perhitunan luas bidang pada bagian 1 .

$\mathrm{p} \times \mathrm{l}=0,25 \times 0,7=0,175 \mathrm{~m}^{2}$

$\mathrm{p} \times \mathrm{l}=1,8 \times 0,2=0,36 \mathrm{~m}^{2}$

$2 \times \frac{1}{2} \mathrm{a} \times \mathrm{t}=2 \times \frac{1}{2} \times 0,28 \times 0,25=0,7 \mathrm{~m}^{2}$

$2 \times \mathrm{p} \times \mathrm{l}=2 \times 0,15 \times 0,3=0,09 \mathrm{~m}^{2}$

$\mathrm{p} \times \mathrm{l}=0,25 \times 0,7=0,175 \mathrm{~m}^{2}$

$2 \times \frac{1}{2} \mathrm{a} \times \mathrm{t}=2 \times \frac{1}{2} \times 0,12 \times 0,3=0,036 \mathrm{~m}^{2}$

Luas $1=0,8555 \mathrm{~m}$

Berikut ini table hasil perhitungan luas bidang 1, 2, 3, 4 dari segmen 1-5 dan hasil volumenya.

Tabel 2. Hasil Perhitungan Volume

\begin{tabular}{|c|c|c|c|c|}
\hline \multicolumn{2}{|c|}{ Luas Bidang } & \multicolumn{3}{|c|}{ Perhitungan Volume cetakan } \\
\hline No & Luas & $\begin{array}{c}\text { Segmen } \\
1 / 5\end{array}$ & $\begin{array}{c}\text { Segmen } \\
2 / 4\end{array}$ & $\begin{array}{c}\text { Segmen } \\
3\end{array}$ \\
\hline 1 & $0,8555 \mathrm{~m}^{2}$ & \multirow[t]{4}{*}{$7,4305 \mathrm{~m}^{3}$} & \multirow[t]{4}{*}{$6,044 \mathrm{~m}^{3}$} & \multirow[t]{4}{*}{$6,648 \mathrm{~m}^{3}$} \\
\hline 2 & $1,3877 \mathrm{~m}^{2}$ & & & \\
\hline 3 & $0,6565 \mathrm{~m}^{2}$ & & & \\
\hline 4 & $0,189 \mathrm{~m}^{2}$ & & & \\
\hline Tot & lume 32 & & & \\
\hline
\end{tabular}

Dari hasil perhitungan didapatkan nilai volume

beton sebesar 32,949 $\mathrm{m}^{3}$ dan hasil volume pada program solidwork didapatkan nilai sebesar $32,7463591 \mathrm{~m}^{3}$ 
Persentase $\frac{32,7463591}{32,949 m^{3}}(100 \%)=99,384 \%$

\subsection{Perhitungan Tekanan Hidrostatis}

Untuk menghitung tekanan yang terjadi pada cetakan akibat dari beton curah maka penulis melakukan analisa tekanan khususnya pada segmen 3 yang lebih sering terjadi cacat sehingga didapat nilai distribusi tekanan dari titik permukaan atas beton yaitu tinggi benda kerja yang diamati 1,4 meter, sampai 1,9 meter dari permukaan meja kerja.
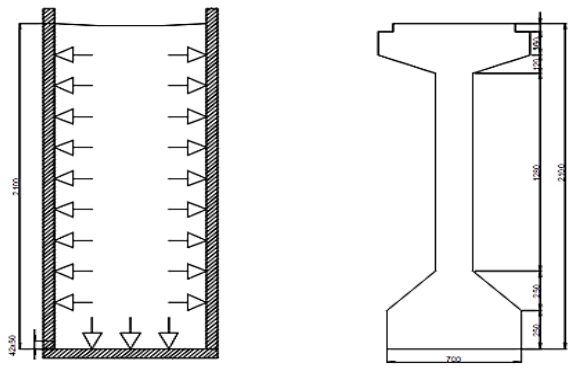

Gambar 9. Tekanan Hidrostatis

Peritungan tekanan hidrostatis pada tinggi 1,9 meter

$$
\begin{gathered}
P_{h}=\rho \cdot g \cdot h=2400 \mathrm{~kg} / \mathrm{m}^{3} \cdot 9,8 \mathrm{~m} / \mathrm{s}^{2} \cdot 1,9 \mathrm{~m} \\
P_{\text {total }}=P_{h}+P_{\text {udara }}=144688 \mathrm{~Pa}
\end{gathered}
$$

Tabel 3. Perhitungan Tekanan Hidrostatis

\begin{tabular}{|l|l|l|l|}
\hline $\begin{array}{c}\text { Tinggi } \\
(\mathrm{m})\end{array}$ & $\begin{array}{c}\text { Gravitasi } \\
\mathrm{m} / \mathrm{s}^{2}\end{array}$ & $\begin{array}{c}\text { Berat Jenis } \\
\mathrm{kg} / \mathrm{m}^{3}\end{array}$ & Tekanan \\
\hline 1,9 & 9,8 & 2400 & $44688 \mathrm{~Pa}$ \\
\hline 1,8 & 9,8 & 2400 & $42336 \mathrm{~Pa}$ \\
\hline 1.7 & 9,8 & 2400 & $39984 \mathrm{~Pa}$ \\
\hline 1,6 & 9,8 & 2400 & $37632 \mathrm{~Pa}$ \\
\hline 1,5 & 9,8 & 2400 & $35280 \mathrm{~Pa}$ \\
\hline 1,4 & 9,8 & 2400 & $32928 \mathrm{~Pa}$ \\
\hline
\end{tabular}

\subsection{Perhitungan Momen Gaya}

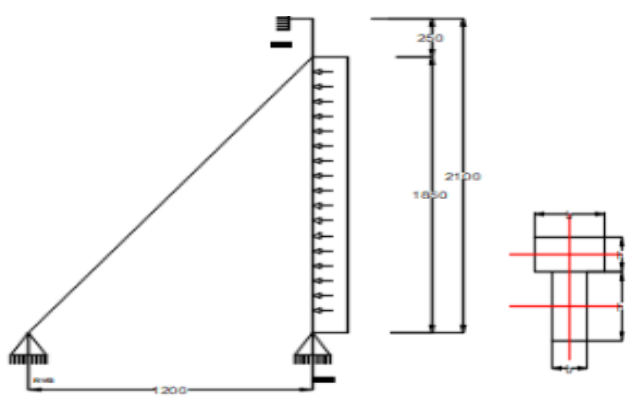

Gambar 10. Diagram Benda Bebas

$$
\begin{aligned}
& \mathrm{RVB}=\frac{\mathrm{F} \cdot \mathrm{A}}{\mathrm{L}}=\frac{144688 \cdot 1,05}{1,85}=82120,2 \mathrm{~N} \cdot \mathrm{m} \\
& \mathrm{RVA}=\frac{\mathrm{F} \cdot \mathrm{A}}{\mathrm{L}}=\frac{144688.0,8}{1,85}=62657,7 \mathrm{~N} \cdot \mathrm{m} \\
& \begin{array}{l}
\mathrm{F} y=0 \mathrm{RVA}+\mathrm{RVb}-\mathrm{F} 1=082120,2+ \\
62657,7-144688=0
\end{array}
\end{aligned}
$$

$\operatorname{Iax}=\frac{1}{12} b h^{3}=\frac{1}{12} 1200.8^{3}=51200 \mathrm{~mm}^{4}$

Iay $=\frac{1}{12} b^{3} \mathrm{~h}=\frac{1}{12} 1200^{3} .8=1,152 \mathrm{e} 9 \mathrm{~mm}^{4}$

$I b x=\frac{1}{12} b h^{3}=\frac{1}{12} 8 \cdot 80^{3}=34133,33 \mathrm{~mm}^{4}$

$I b y=\frac{1}{12} b h^{3}=\frac{1}{12} 8^{3} \cdot 80=40960 \mathrm{~mm}^{4}$
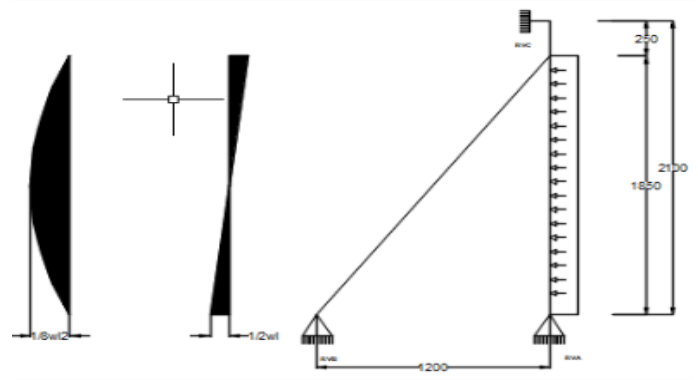

Gambar 11. Reaksi Gaya

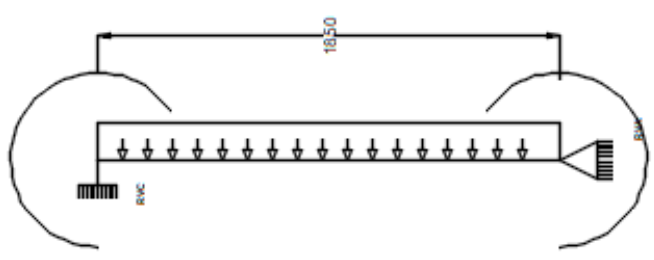

Gambar 12. Momen Gaya

$\operatorname{Mmax}=\frac{\mathrm{WL}}{8}=\frac{144688 \cdot 1,85}{8}=33459,1 \mathrm{~N} . \mathrm{m}$

$\sigma=\frac{M}{S}=\frac{M y}{I}=\frac{33459,1.0,008}{0,01152}=25987650,5 \mathrm{~N} / \mathrm{m}^{2}$

$\sigma=\frac{M}{S}=\frac{M y}{I}=\frac{33459,1.0,08}{0,01152}=259876505 \mathrm{~N} / \mathrm{m}^{2}$

Lendutan Maksimal

$\delta=\frac{5 M L}{384 E I}=\frac{5 \cdot 144688 \cdot 1,85^{3}}{384 \cdot 51707000 \cdot 0,01152}=2,0025 \mathrm{~mm}$

$E I y=\frac{W I^{3}}{384}=\frac{144688 \cdot 1,85^{3}}{384}=2197,5 \mathrm{~N} \cdot \mathrm{m}^{3}$

\subsection{Hasil Analisis Statik}

Untuk analisis distribusi tegangan beban statis dengan menggunakan software solidwork dilakukan terhadap rangka cetakan yang akan dianalisis menggunakan tipe Von Misses Stress. Analisis dilakukan untuk mengetahui kekuatan rangka cetakan terhadap beban statis untuk 
mengetahuai kekuatan rangka, agar dapat mengetahui nilai tegangan yang terjadi. Pembebanan terhadap rangka ditunjukkan pada anak panah yang berwarna merah muda dengan diasumsikan gaya pada jarak 1,9 meter dangan tekanan sebesar 144688 Newton/metar ${ }^{2}$.

Material yang digunakan untuk membuat rangka cetakan adalah baja karbon tipe A36. Dengan profil siku ketebalan pelat $8 \mathrm{~mm}$, tebal frame $8 \mathrm{~mm}$,panjang frame $80 \mathrm{~mm}$ dan ukuran $41540 \mathrm{~mm} \times 2100 \mathrm{~mm}$

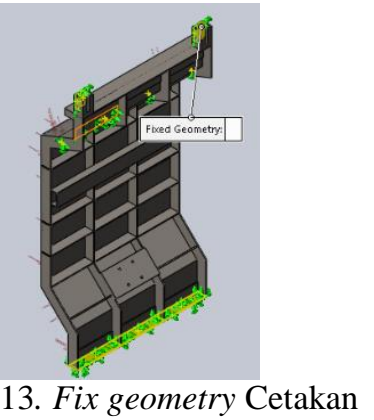

Terdapat 12 Permukaan yang di pakai sebagai acuan fix geometry yaitu pada tempat bracing, tierod dan fastener pelat bagian bawah.

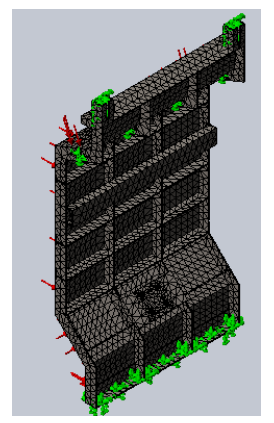

Gambar 14. Meshing

Tabel 4. Meshing

\begin{tabular}{|l|l|}
\hline Master Used & Solid Mesh \\
\hline Total Nodes & 33077 \\
\hline Total Elemen & 16427 \\
\hline Elemen Size & $48.9735 \mathrm{~mm}$ \\
\hline Tolerance & $2.44868 \mathrm{~mm}$ \\
\hline Maximum Aspect Ratio & 37.539 \\
\hline \% of elements Aspect Ratio <3 & 10,8 \\
\hline \% of elements Aspect Ratio > 10 & 4,68 \\
\hline
\end{tabular}

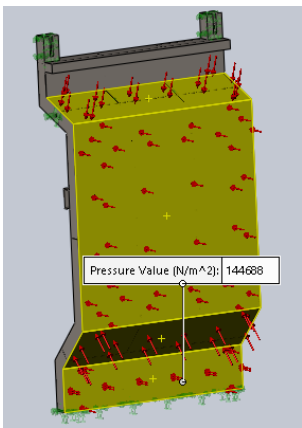

Gambar 15. Preasure load
Hasil simulasi pengujian analisis distribusi tegangan pada beban statis tipe Von Misses Stress yang telah dilakukan terhadap rangka cetakan stand ditunjukkan pada gambar 16 .

$$
\text { Analisis distribusi tegangan }
$$

ditunjukkan dengan warna merah pada tegangan maksimum, dan warna biru pada tegangan minimum. Dari analisis yang dilakukan didapatkan hasil tegangan maksimum sebesar 4,772e+008N/m^2 dan tegangan minimum sebesar $1,574 \mathrm{e}+004 \mathrm{~N} / \mathrm{m}^{\wedge} 2$ Berdasarkan perhitungan didapatkan nilai matrial sudah mengalami deformasi atau patah. Karena tegangan maksimal sudah sebanding atau lebih besar dari yield strength material.

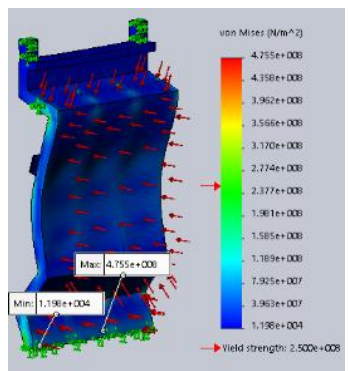

Gambar 16. Hasil Analisis Statis

Besarnya perubahan material yang terjadi akibat beban yang diberikan (displacement) ditunjukkan pada gambar 17. Berikut ini.

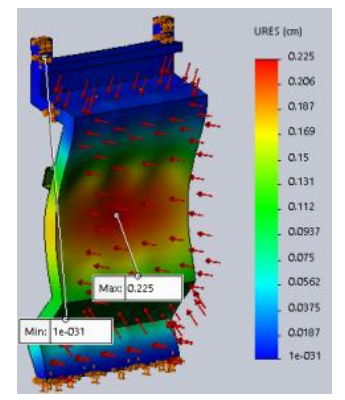

Gambar 17. Perubahan (displacement)

Dari analisis yang dilakukkan pada cetakan, perubahan (displacement) maksimum sehingga terjadi deformasi plastis ditunjukkan dengan warna merah $2,25 \mathrm{~mm}$ dengan jarak displacement $2,25 \mathrm{~mm}$. Pada daerah berwarna biru muda adalah daerah elastis. Sedangkan daerah berwarna hijau adalah daerah transisi elastis dan plastis. Pada daerah kuning material sudah bersifat plastis atau tidak dapat di kembalikan ke bentuk semula.

\subsection{Analisis Dinamika Struktur}

Hasil simulasi analisis distribusi tegangan dinamis tipe Von Misses Stress yang 
telah dilakukan terhadap rangka cetakan ditunjukkan pada gambar 18 .

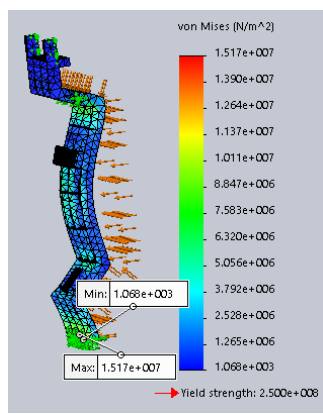

Gambar 18. Hasil Analisis dinamika

Analisis distribusi tegangan ditunjukkan dengan warna merah pada tegangan maksimum, dan warna biru pada tegangan minimum. Dari analisis yang dilakukan didapatkan hasil tegangan maksimum sebesar $1.517 \mathrm{e}+007 \mathrm{~N} / \mathrm{m}^{\wedge} 2$ pada node 9352 dan tegangan minimum sebesar $1.068 \mathrm{e}+003 \mathrm{~N} / \mathrm{m}^{\wedge} 2$ pada node 9511 . Besarnya perubahan material yang terjadi akibat beban yang diberikan (displacement) ditunjukkan pada gambar 19 berikut ini.

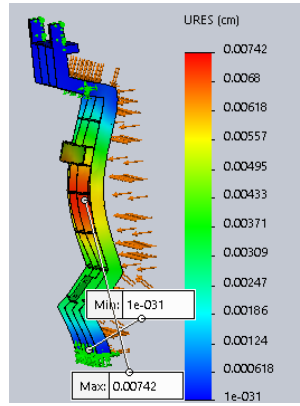

Gambar 19. Perubahan (displacement)

Perubahan (displacement) maksimum ditunjukkan dengan warna merah $0,0742 \mathrm{~mm}$ dan perubahan minimum ditunjukkan dengan warna biru $0 \mathrm{~mm}$. Gambar 20. menggambarkan hasil kecepatan pergeseran struktur.

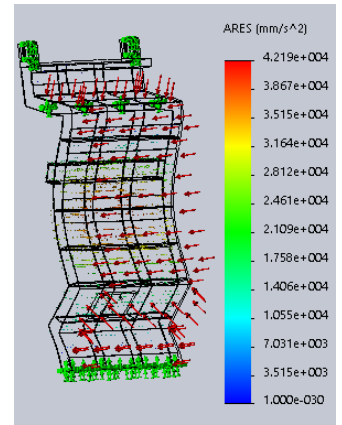

Gambar 20. Kecepatan Pergeseran Struktur

Nilai kecepatan pergerakan cetakan dengan nilai minimal yaitu $0.000 \mathrm{e}+000 \mathrm{~mm} / \mathrm{s}^{\wedge} 2$ pada Node: 65 dan nilai kecepatan maksimal 4.219e+004mm $/ \mathrm{s}^{\wedge} 2$ pada Node: 22295 . Fungsi eksitasi yang diberikan berupa vibrasi dari nilai getaran mesin vibrator maksimum. Hasil analisis dinamika struktur terbagi dari dua bagian, yaitu analisis Normal Modes dan analisis Respon Frekuensi (FRF). Hasil analisis respon frekuensi adalah grafik FRF (Frequency Response Function) terdiri dari 3 parameter yaitu perpindahan (deformation/displacement), kecepatan (velocity), dan percepatan (acceleration).Dalam standar respon fungsi parameter tersebut ditampilkan dalam grafik FRF yaitu grafik receptance, mobilit, dan accelerance. Grafik receptance, mobility, dan accelerance ialah grafik yang menunjukkan hasil dari pembagian antara ketiga parameter dengan gaya (force). Untuk Frekuensi respon fungsi pada analisis model diperoleh frekuensi pribadi natural di tunjukan pada gambar 21 .

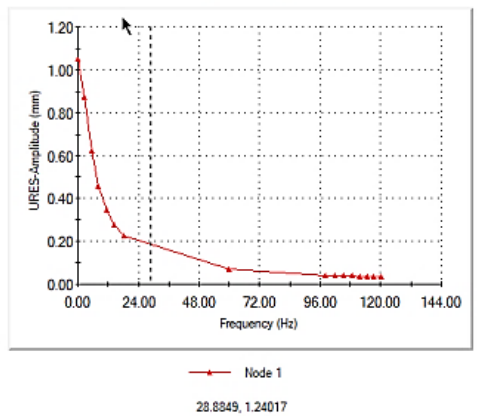

Gambar 21. Grafik Frekuensi Pribadi

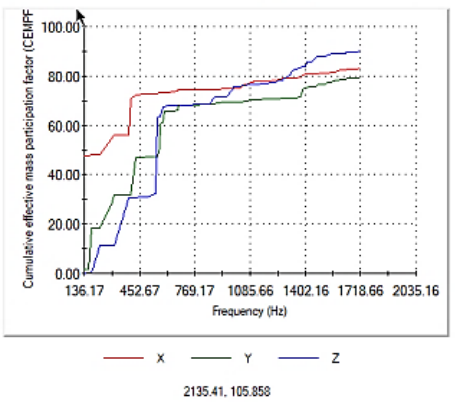

Gambar 22. Grafik Frekuensi vs Cumulative Effective mass Participation

Plot amplitude yang dihasilkan dengan nilai frekuensi awal $120 \mathrm{hz}$ pada analisis menggunakan metode frekuensi, maka nilai minimal yang dihasilkan yaitu : 0.00 pada node 61 dan nilai maksimal yang di hasilkan sebesar 1,106e-001 dan nilai maksimal pada node 18470 ke arah sumbu $x$ 


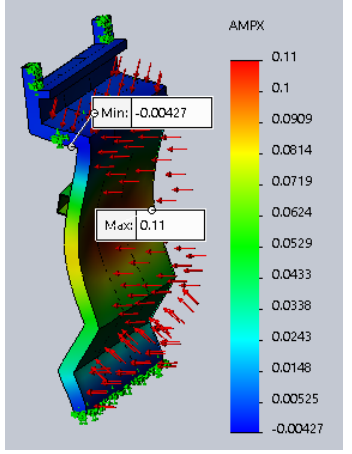

Gambar 23. Efek Getaran Frekuensi X

Plot amplitude yang di hasilkan pada cetakan dengan nilai minimal $-4,404 \mathrm{e}-002 \mathrm{~Hz}$ pada node 65 dan nilai maksimal sebesar 4,711e-002 dan nilai maksimal pada node 10685 ke arah sumbu $\mathrm{z}$.

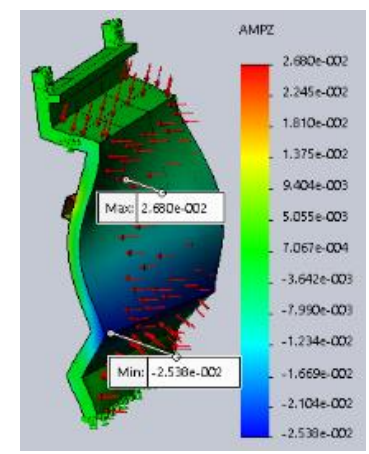

\section{Gambar 24. Efek Getaran Frekuensi Z}

Plot amplitude yang dihasilkan pada cetakan dengan nilai minimal $-5,365 \mathrm{e}-003 \mathrm{~Hz}$ dan nilai maksimal sebesar 5,591e-003 pada node 65 dan nilai maksimal pada node $861 \mathrm{ke}$ arah sumbu $\mathrm{y}$.

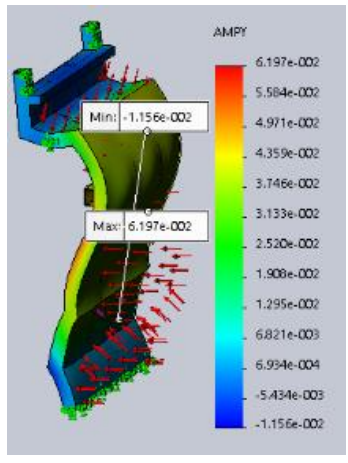

Gambar 25. Efek Getaran

Plot resultan amplitude yang dihasilkan pada cetakan dengan nilai minimal 0.00 pada node 65 dan nilai maksimal 1,480e-001 Hz dan nilai maksimal pada node 2687.

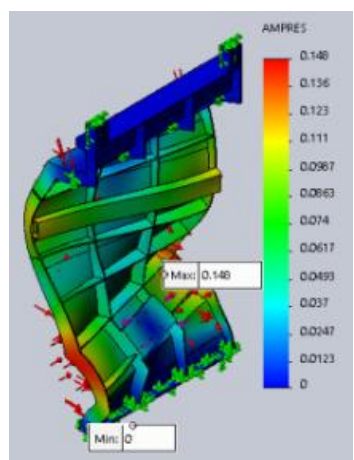

Gambar 26. Efek Getaran Frekuensi $229.64 \mathrm{~Hz}$

Berikut ini adalah data pengaruh gataran terhadap kecenderungan cetakan untuk mengalami perubahan posisi. Untuk melihat hasil analisis maka terdapat faktor penting, faktor yang penting yaitu dalam penentuan parameter kecepatan sudut $\omega\left(\frac{\mathrm{rad}}{\mathrm{sec}}\right)$ frekuensi $(\mathrm{Hz})$ dan waktu (secon) yang diambil dari hasil analisis.

Tabel 5. Hasil Frekuensi Getaran

\begin{tabular}{|c|c|c|c|}
\hline $\begin{array}{c}\text { Frequency } \\
\text { Number }\end{array}$ & Rad/sec & Hertz & Seconds \\
\hline 1 & $\mathbf{8 6 8 . 1 3}$ & $\mathbf{1 3 8 . 1 7}$ & $\mathbf{0 . 0 0 7 2 3 7 6}$ \\
\hline 2 & $\mathbf{1 0 2 3 . 3}$ & $\mathbf{1 6 2 . 8 6}$ & $\mathbf{0 . 0 0 6 1 4 0 1}$ \\
\hline 3 & $\mathbf{1 1 2 0 . 1}$ & $\mathbf{1 7 8 . 2 6}$ & $\mathbf{0 . 0 0 5 6 0 9 7}$ \\
\hline 4 & $\mathbf{1 4 4 2 . 9}$ & $\mathbf{2 2 9 . 6 4}$ & $\mathbf{0 . 0 0 4 3 5 4 7}$ \\
\hline
\end{tabular}

\subsection{Tindakan Rekomendasi}

Untuk mengurangi besar pergeseran pada cetakan akibat tekanan beton dan getaran vibrator, maka perlu dilakukan tindakan dengan membuat atau menambahkan jumlah fix support pada bagian tengah pelat dan penambahan ketebalan tumpuan atau bisa juga dengan penambahan baja UNP atau IWF 150.75 pada cetakan. Gambar di bawah menunjukan penambahan fix support. Sebelum menjalankan simulasi, terlebih dahulu dilakukan pemberian beban berupa tekanan dengan distribusi merata yang nilainya $144688 \mathrm{~Pa}$ pada 4 permukaan yang bersensentuhan langsung dengan beton, kemudian langkah selanjutnya yaitu melakukan analisis (run simulation). Hasil analisis distribusi tegangan statik pada program solidwork ditunjukkan dengan warna merah pada tegangan maksimum, dan warna biru pada tegangan minimum. Dari analisis yang dilakukan didapatkan hasil tegangan maksimum sebesar 3,296e+008 N/m² pada node 9352 dan tegangan minimum sebesar $1,379+004 \mathrm{~N} / \mathrm{m}^{\wedge} 2$ 
pada node 9511. Untuk lebih jelas perhatikan gambar 27 berikut ini menunjukan hasil nilai tegangan.

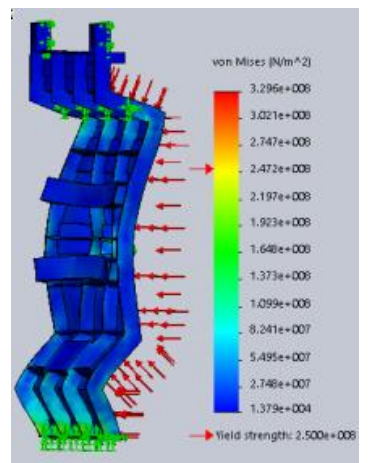

Gambar 27. Von mises Stress

Berdasarkan perhitungan didapatkan nilai matrial sudah mengalami deformasi atau patah. Karena tegangan maksimal sudah lebih besar dari yield strength material. Besarnya perubahan material yang terjadi akibat beban yang diberikan (displacement) Nilai jarak maksimal yang terjadi yaitu $0,952 \mathrm{~mm}$ pada node 9352 dan jarak pergeseran minimal yaitu 1e-030mm pada node 9511 .

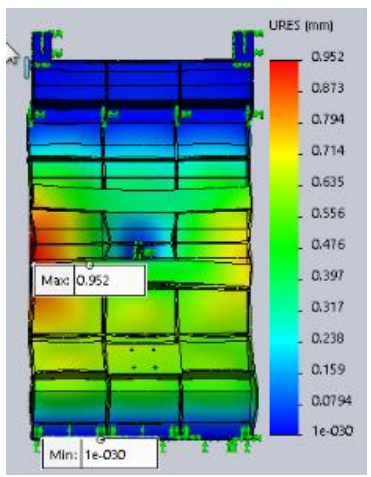

Gambar 28. Jarak Pergeseran

\section{KESIMPULAN}

Berdasarkan dari uraian pembahasan analisis Kegagalan Produk Presered Concret Girder I Akibat Deformasi Cetakan Dengan Menggunakan Metode Elemen Hingga yang telah dijelaskan pada bab sebelumnya, maka dapat ditarik kesimpulan secara keseluruhan bahwa :

1. Untuk menganalisis tekanan yang terjadi pada cetakan presered concrete girder I menggukan analisis difleksi 2D DOF dengan nilai momen maksimal sebesar $33459,1 \mathrm{~N} . \mathrm{m}$, tegangan maksimal $285864156.5 \mathrm{~N} / \mathrm{m}^{2}$ dan lendutan maksimal sebesar 2,0025 $\mathrm{mm}$ serta dengan menggunakan analisis menggunakan simulasi pada program solidwork tegangan maksimal $492370000 \mathrm{~N} / \mathrm{m}^{2}$, lendutan maksimum $2.3242 \mathrm{~mm}$.

2. Setelah analisis yang dilakukan baik itu perhitungan manual atau menggunakan solidwork, maka perlu ditambahkan pelat pada bagian tengah cetakan dengan dibantu bracing sebagai penyangga tumpuan seperti yang dijelaskan pada bab iv untuk tindakan rekomendasi.

\section{DAFTAR PUSTAKA}

[1] Ahmad Kholil, Catur Setyawan, Heru Saputro. April. 2015. Analisis Karakteristik Getaran Struktur Lengan Ayun Sepeda Motor Jenis Suspensi Twinshock Menggunakan Metode Elemen Hingga dan Eksperimental Jurnal Konversi Energi dan Manufaktur UNJ.

[2] Al Ichlas Imran, Kadir. Mei 2017. Simulasi tegangan von mises dan safety factor gentry crane kapasitas 3 ton.

[3] Bambang Setyono, Mrihrenaningtyas, Abdul Hamid. 2016. Perancangan dan analisis kekuatan frame sepeda hybrid "Trisona" menggunakan software autodesk invertor.

[4] Basri Hasan. Maret 2007. Analisis Lubrikasi Bantalan Bola akibat Getaran dengan Metode Elemen Hingga dan Moditikasi Struktur Mesin Penyeimbang Mini.

[5] E.P. POPOV Mekanika Teknik

[6] Fajar Ari Wandono1, Agus Harno Nurdin Syah 2017 Prediksi kekuatan struktur alat uji getaran engine LSU series menggunakan metode elemen hingga.

[7] Ferdinand L Singer, Andrew Pytel Ilmu Kekuatan Bahan Erlangga 1995

[8] http://phisiceducation09.blogspot.com diakses 17.36 Juli 2019

[9] http://teknologisurvey.com diakses 15.19 Juni 2019.

[10] http://usmanalli.blogspot.com 14.23 Juni 2019. 